\title{
Occupational exposure to natural radionuclides due to mining activities in Ibadan, Southwestern Nigeria
}

\author{
J.A. ADEMOLA ${ }^{1}$, N.E. OKPALAONWUKA ${ }^{1}$
}

(Manuscript received 15 September 2009, accepted 24 November 2009)

ABSTRACT The activity concentrations of potassium, uranium and thorium in minerals and soil samples from a mining site in Ibadan, Southwestern Nigeria were measured using gamma ray spectroscopy method. Effective dose per annum has been calculated from the activity concentrations of dominant gamma-emitting natural radionuclides, potassium, uranium and thorium. Samples collected include minerals (beryl, quartz and feldspar), soil samples from the mining pits, heaps and undisturbed land around the mining site. The activity concentrations of ${ }^{40} \mathrm{~K},{ }^{238} \mathrm{U}$ and ${ }^{232} \mathrm{Th}$, respectively in $\mathrm{Bq} \mathrm{kg}^{-1}$ in the mineral samples were as follows: $1985 \pm 16$, $4.8 \pm 0.9$ and $11.8 \pm 5.8$ for beryl sample, $115.1 \pm 27.9,5.0 \pm 1.3$ and $6.3 \pm 5.0$ for feldspar samples and $1421 \pm 122,<4.8$ and $20.1 \pm 3.5$ for quartz samples. For the soil samples, the mean activity concentrations of ${ }^{40} \mathrm{~K},{ }^{238} \mathrm{U}$ and ${ }^{232} \mathrm{Th}$, respectively, were $314.2 \pm 5.7,27.7 \pm 2.6$ and $11.5 \pm 5.9 \mathrm{~Bq} \mathrm{~kg}^{-1}$ for soil samples from the pits and $278.1 \pm 5.4,21.1 \pm 2.0$ and $15.3 \pm 7.5 \mathrm{~Bq} \mathrm{~kg}^{-1}$ for soil samples from heaps. The mean activity concentrations of soil samples from the undisturbed land around the mining site were $194.3 \pm 25.2,14.5 \pm 5.1$ and $13.3 \pm 5.9 \mathrm{~Bq} \mathrm{~kg}^{-1}$ for ${ }^{40} \mathrm{~K},{ }^{238} \mathrm{U}$ and ${ }^{232} \mathrm{Th}$, respectively. The effective dose to which the miners are exposed according to exposure scenarios were calculated as $89.9 \mu \mathrm{Sv} \mathrm{y}^{-1}$ for digging and handling of soil and mineral samples in the pit and $63.6 \mu \mathrm{Sv} \mathrm{y}^{-1}$ for handling of soil and mineral samples at the heaps.

Keywords: Occupational exposure / natural radionuclides / effective dose / mining

RÉSUMÉ Exposition professionnelle aux radionucléides naturels émis par les activités minières à Ibadan au sud-ouest du Nigéria.

Les concentrations en activité de potassium, d'uranium et de thorium dans les minerais et échantillons de sol provenant d'un site minier à Ibadan, dans le sud-ouest du Nigéria ont été mesurées par spectroscopie des rayons gamma. La dose efficace annuelle a été calculée à partir des concentrations en activité des radionucléides naturels dominant, du potassium, de l'uranium et du thorium émetteurs de rayons gammas. Les échantillons rassemblés incluent des minerais (béryl, quartz et feldspath), des échantillons de sol provenant des puits d'exploitation, de prélèvements de terrils et de terre non perturbée autour du site minier. Les concentrations en activité de ${ }^{40} \mathrm{~K},{ }^{238} \mathrm{U}$ et ${ }^{232} \mathrm{Th}$, sont respectivement, en $\mathrm{Bq} \mathrm{kg}{ }^{-1}$, dans les échantillons minéraux de $: 1985 \pm 16,4,8 \pm 0,9$ et $11,8 \pm 5,8$ pour l'échantillon de béryl, 115,1 $\pm 27,9,5,0 \pm 1,3$ pour des échantillons de feldspath et $1421 \pm 122,<4,8$ et $20,1 \pm 3,5$ pour des échantillons de quartz. Pour les échantillons de sol, les concentrations en activité moyenne de ${ }^{40} \mathrm{~K},{ }^{238} \mathrm{U}$ et ${ }^{232} \mathrm{Th}$, respectivement, étaient de $314,2 \pm 5,7,27,7 \pm 2,6$ et $11,5 \pm 5,9 \mathrm{~Bq} \mathrm{~kg}^{-1}$ pour des échantillons de sol provenant des

\footnotetext{
1 Department of Physics, University of Ibadan, Ibadan, Oyo State, Nigeria.
} 
puits et $278,1 \pm 5,4,21,1 \pm 2,0$ et $15,3 \pm 7,5 \mathrm{~Bq} \mathrm{~kg}^{-1}$ pour des échantillons de sol provenant des terrils. Les concentrations en activité moyenne des échantillons de sol provenant de sols non-perturbés autour du site minier étaient de 194,3 $\pm 25,2,14,5 \pm$ 5,1 et $13,3 \pm 5,9 \mathrm{~Bq} \mathrm{~kg}^{-1}$ pour ${ }^{40} \mathrm{~K},{ }^{238} \mathrm{U}$ et ${ }^{232} \mathrm{Th}$, respectivement. La dose efficace à laquelle les mineurs sont exposés selon des scénarios d'exposition ont été calculées ; $89,9 \mu \mathrm{Sv} \mathrm{y}^{-1}$ pour le creusement et la manipulation des échantillons de sol et de minerai dans le puits et 63,6 le $\mu \mathrm{Sv}^{-1}$ pour la manipulation des échantillons de sol et de minerai des terrils.

\section{Introduction}

Occupational exposure to radiation can occur as a result of various human activities. These include work associated with the different stages of the nuclear fuel cycle, the use of radioactive sources and X-ray machines in medicine, scientific research, education, agriculture and industry, and occupations that involve the handling of materials containing radionuclides (IAEA, 1999).

Mining is the extraction of valuable minerals or other geological materials from the earth, usually from ore body, vein or seam. Any material that cannot be grown from agricultural processes, or created artificially in a laboratory or factory, is usually mined. Mining in a wider scope can also include extraction of petroleum, natural gas and even water. Mining has different type of environmental damage, which includes ecological disturbance, destruction of natural flora and fauna, pollution of air, land and water, geological hazards caused by instability of soil and rock masses, landscape degradation and radiation hazards (Adekoya, 2003).

It has been found that the earth crust contains naturally occurring radioactive material (NORM) in varying quantity, thus humans are naturally exposed to radiation (UNSCEAR, 2000). The existence of natural radioactivity in the ores and their waste has long been recognized. Human activities of various kinds enhance the radiation level of the environment. Mining is one of such activities that enhance the natural radioactivity level of the environment, thus working activities that involves natural radioactive material is source of radiation exposure (UNSCEAR, 2000). Ademola (2008) reported high activity concentrations of natural radionucldes in tin tailings.

In the area of mining, the specific concerns are occupational radiation exposure of miners. Miners are exposed to airborne radon $\left({ }^{222} \mathrm{Rn}\right)$, thoron $\left({ }^{220} \mathrm{Rn}\right)$ and shortlived decay products, long-lived radionuclides in ore dust, and external gamma radiation. The processed solid wastes are usually disposed off on open land, where they undergo a natural process of weathering (Sam and Awad Al-Geed, 2000).

According to Pires do Rio et al. (2002), non-nuclear mining and milling industries have the potential of causing radiological problem. These include 
niobium, phosphate, coal, gold, tin, copper and lead industries. Beryl, quartz and feldspar are mined at Ibadan, Southwestern Nigeria. The mining started since the early 90's and has since been a source of living for young able men in the area. The mining activity at the mining site is the open sky activities. Beryl occurs in granite pegmatite and greisens (Battey and Pring, 1997). Beryllium metal of which beryl is the ore, is finding increasing use in industries, in alloy with copper, in electrical porcelain, for the windows of X-ray tubes and in fluorescent lighting tube. The transparent coloured varieties are used as gemstone. Quartz occurs commonly in prismatic crystals with unequally developed rhombohedral termination. It is used in the building industry as concrete and mortar. It is also used as filter and diluents, as abrasive and for making moulds for metal casting, in glass industry, ceramics and refractories. Its piezoelectric property leads to its use in oscillators and pressure gauge (Battey and Pring, 1997). The type of feldspar considered in this work is the K-feldspar; it is alkali feldspar and is made up of $50-60 \%$ of all igneous rock (Deer et al., 1992). They are used in the manufacture of glass and ceramics.

In Nigeria there is a general lack of information regarding radiation doses from the non-nuclear industries. The purpose of this work is to assess occupational exposure due to radiological impart of the mining of beryl, quartz and feldspar in Ibadan, Southwestern Nigeria. The study does not consider exposure to radon gas.

\section{Materials and methods}

The study area

The study area is a mining site located in Ibadan, Southwestern Nigeria. It is between the reference grid of latitude $7^{\circ} 9^{\prime} \mathrm{N}$ and $7^{\circ} 15^{\prime} \mathrm{N}$ and between longitude $3^{\circ} 55^{\prime} \mathrm{E}$ and $4^{\circ} 00^{\prime} \mathrm{E}$ (Itiola, 1998). Ibadan is the third largest city in Africa situated in the South Western part of Nigeria with a population of over 2 million people.

The climate is that of tropical rain forest being part of the tropics and is characterized by hot humid with alternating wet and dry seasons. In terms of vegetation, it is generally thick especially along river courses, which is a characteristic of the tropical rainforest. Light forests are found only where there have been human activities like farming, tree falling, mining etc. According to Itiola (1998), the area host pegmatite. Pegmatites are known to host a wide range and perhaps largest number of economic minerals, both metallic and non-metallic. The area is thus rich in minerals like gemstone, mica, feldspar, lepidolite, quartz etc. Figure 1 is the geological map of the study area showing mineralized zones. 


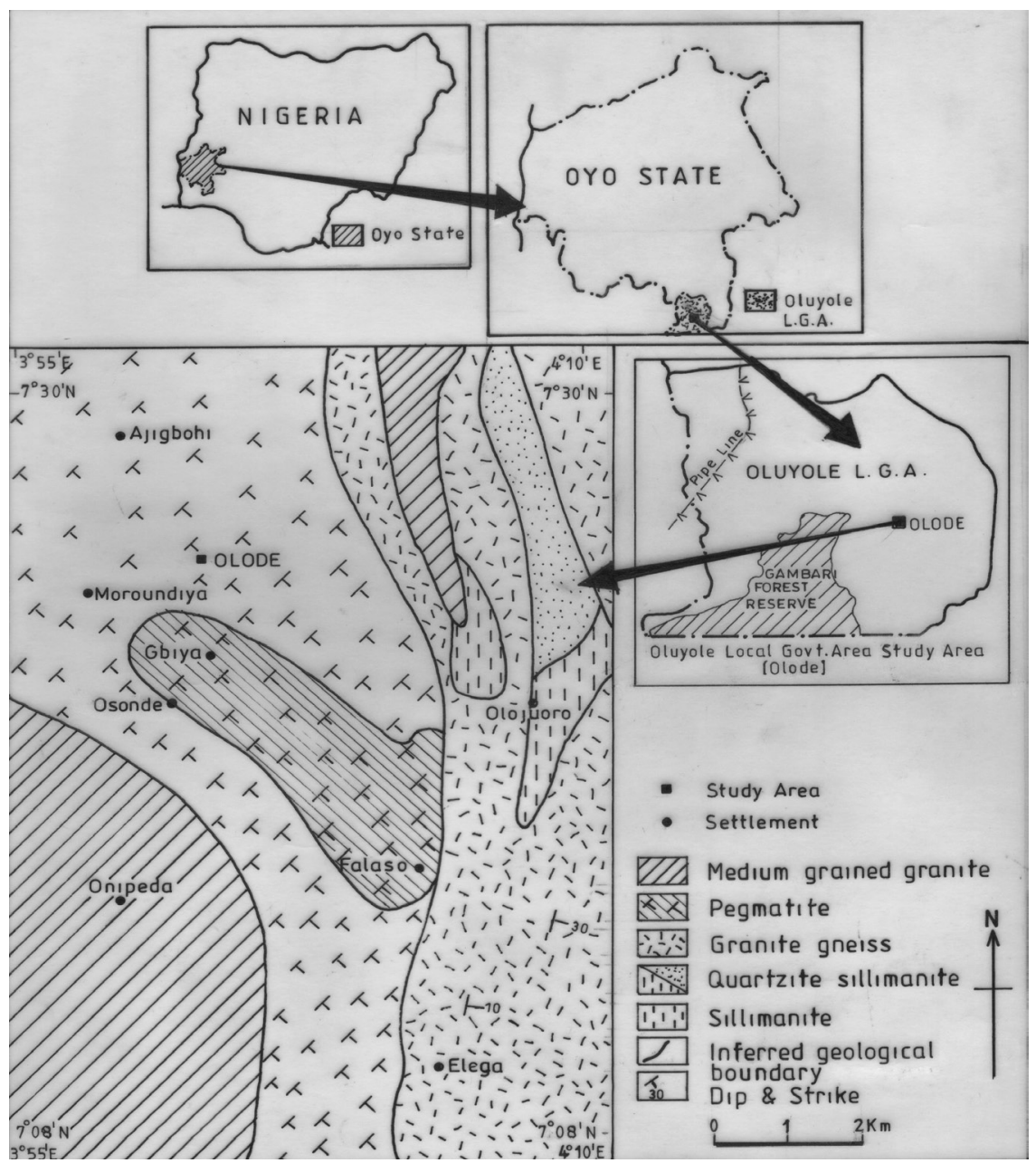

Figure 1 - Geological map of the study area showing mineralized zones.

Carte géologique de la zone étudiée montrant la localization des minerais.

\section{Sample collection and preparation}

Soil samples and minerals were collected from the mining site. A total of forty soil samples and six samples of minerals were collected. These include fifteen soil samples from different heaps at the mining site, fifteen soil samples from different pits at the mining site and ten soil samples from land around the mining site, which has not been tampered with mining activity. The mineral comprised of one sample of beryl, three samples of feldspar, and two samples of quartz. Much of the 
minerals could not be collected because of their scarcity and exorbitant price of those available at the time of sample collection. Samples from the land around the mining sites were obtained by clearing the surface vegetation from a location after which, a core sample was manually taken from it to a depth of $5 \mathrm{~cm}$.

Each sample was oven dried in the laboratory at a temperature of $100{ }^{\circ} \mathrm{C}$ until a constant weight was attained. They were then crushed and passed through a $2 \mathrm{~mm}$ mesh sieve. A mass of $200 \mathrm{~g}$ each of the sieved soil samples were put in plastic containers. The containers were sealed and kept for more than four weeks, which was a sufficient time required to attain a state of secular equilibrium.

\section{Sample measurement}

The activity concentrations of ${ }^{40} \mathrm{~K},{ }^{238} \mathrm{U}$ and ${ }^{232} \mathrm{Th}$ were measured using gamma ray spectroscopy method. The measuring system consists of a scintillation detector sealed with a photo multiplier tube and connected through a preamplifier base to a Canberra series 10 - plus multi-channel analyzer (MCA). The detector is a $7.6 \mathrm{~cm} \times 7.6 \mathrm{~cm} \mathrm{NaI}(\mathrm{Tl})$ (Model No. 802-series). The detector has a resolution of about $8 \%$ at $0.662 \mathrm{MeV}$ of ${ }^{137} \mathrm{Cs}$. The detection efficiency calibration of the system was carried out using reference standard source prepared from Rocketdyne Laboratories, Canoga Park, Californian, USA, which is traceable to a mixed standard gamma source (No ENV 950050) by Analytic Inc. Atlanta, Georgia (USA). The $1.460 \mathrm{MeV}$ photopeak was used for the measurement of ${ }^{40} \mathrm{~K}$ while the $1.760 \mathrm{MeV}$ photopeak from ${ }^{214} \mathrm{Bi}$ and the $2.614 \mathrm{MeV}$ photopeak from ${ }^{208} \mathrm{Tl}$ were used for the measurement of ${ }^{238} \mathrm{U}$ and ${ }^{232} \mathrm{Th}$, respectively. Each of the samples was counted for 36000 seconds.

\section{Activity concentration}

The activity concentrations of ${ }^{40} \mathrm{~K},{ }^{238} \mathrm{U}$ and ${ }^{232} \mathrm{Th}$ in the soil and mineral samples were calculated using the equation given below:

$$
C=\frac{A}{E_{p} t Y m}
$$

where $C$ is the activity concentration in $\mathrm{Bq} \mathrm{kg}^{-1}, A$ is the net area of the photopeak for each sample, $E_{p}$ is the detection efficiency for each of the radionuclides, $t$ is the counting time, $Y$ is the gamma yield, that is the fraction of the $\gamma$-rays of the particular energy per disintegration and $m$ is the mass of the sample (Ademola, 2004). The lower limits of detection (LLD) of ${ }^{238} \mathrm{U}\left({ }^{214} \mathrm{Bi}\right),{ }^{232} \mathrm{Th}\left({ }^{208} \mathrm{Tl}\right)$ and ${ }^{40} \mathrm{~K}$ were determined (IAEA, 1989) from the background radiation. The LLD obtained are 4.0, 4.8 and $17.0 \mathrm{~Bq} \mathrm{~kg}{ }^{-1}$, respectively for ${ }^{238} \mathrm{U}\left({ }^{214} \mathrm{Bi}\right),{ }^{232} \mathrm{Th}\left({ }^{208} \mathrm{Tl}\right)$ and ${ }^{40} \mathrm{~K}$. Values below these numbers were taken as being below the detection limit (BDL) of the detector. 


\section{Exposure scenario and pathway}

The mining of beryl, quartz and feldspar by the artisans involves digging to extract the mineral bearing soil, breaking up the big bulks into small bits, sieving and handling of the mineral containing soil. Based on the operation described above, the following scenarios and pathways were considered for the occupational dose assessment.

- Exposure scenario:

- digging and extracting soils that contain the minerals;

- handling soils containing the minerals.

- Exposure Pathways:

- external irradiation by $\gamma$-rays emitted by radionuclides contained in the ground and heaps;

- external exposure from submersion in air contaminated with dust;

- internal irradiation due to inhalation of dust in the air;

- internal irradiation due to inadvertent ingestion of soil.

\section{Dose calculation}

The biological effects per unit of absorbed dose vary with the type of radiation and the part of the exposed. To take account of these variations, a weighted quantity called the effective dose is used (UNSCEAR, 2000).

In determining the effective dose incurred by miners the following generic formulas were used. The total annual effective dose $E(\mu \mathrm{Sv})$ is composed of external dose, $E_{\text {ext }}$, internal dose, $E_{i n t}$, and effective dose due to submersion in air contaminated with dust, $E_{s u b}$;

$$
E=E_{\text {ext }}+E_{\text {int }}+E_{\text {sub }}
$$

The annual internal effective dose, $E_{\text {int }}(\mu \mathrm{Sv})$, is composed of doses from inhalation $E_{i n h}$ and ingestion $E_{\text {ing }}$ (IAEA, 2003), therefore equation (2) becomes

$$
E=E_{\text {ext }}+E_{\text {inh }}+E_{\text {ing }}+E_{\text {sub }}
$$

In a general case, the annual effective dose due to external irradiation by gamma radiation $E_{\text {ext }}(\mu \mathrm{Sv})$ from long lived radionuclide can be expressed by the following equation;

$$
E_{\text {ext }}=\sum_{R} A_{R} D C_{\text {ext }, R} T
$$

where $A_{R}$ is the activity concentration of gamma-ray emitting radionuclides in soil samples $\left(\mathrm{Bq} \mathrm{kg}{ }^{-1}\right), D C_{e x t, R}$ is the effective dose coefficient for radionuclide $R$ in 
TABLE I

Sources and values of constant used.

Sources et valeurs des constantes utilisées.

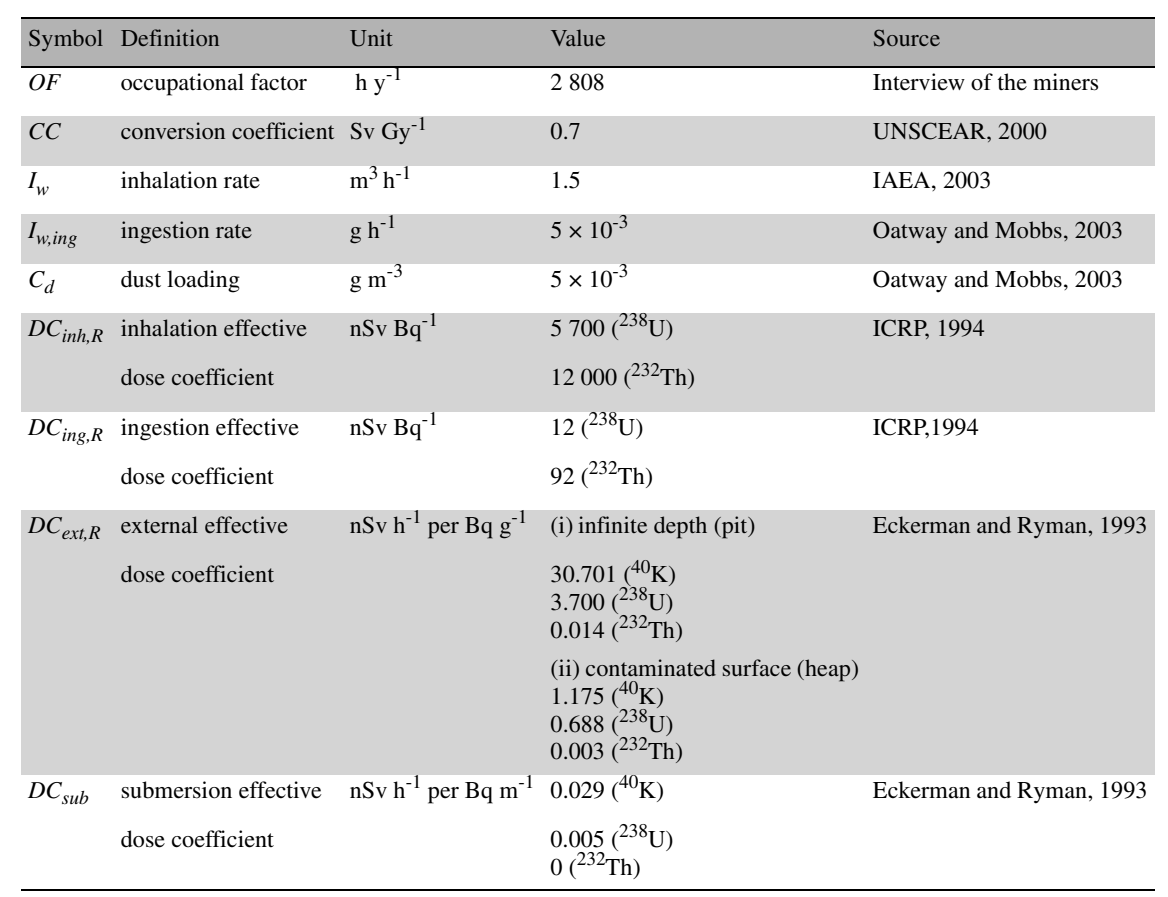

$\mathrm{Sv} \mathrm{h}^{-1}$ per Bq kg${ }^{-1}$ and $T$ is the exposure duration $\left(\mathrm{h} \mathrm{y}^{-1}\right)$. From personal interview of the miners, it was gathered that they spend about 2808 hour per year during their mining occupation. The values of all the constants used in this calculation are given in Table I.

Submersion doses were calculated using equation (4) multiplied by dust loading $C_{d}$, in $\mathrm{g} \mathrm{m}^{-3}$, as shown in the equation below (Mustapha et al., 2007);

$$
E_{\text {sub }}=\sum_{R} A_{R} D C_{\text {ext }, R} T C_{d}
$$

Internal dose due to the inhalation, $E_{i n h}$, of air contaminated with dust is calculated using the equation (Mustapha et al., 2007);

$$
E_{i n h}=\sum_{R} A_{R} D C_{i n h, R} C_{d} I_{w} T
$$

where $D C_{i n h, R}$ is the effective dose coefficient for radionuclide $R$ in $\mathrm{Sv} \mathrm{h}^{-1}$ per $\mathrm{Bq} \mathrm{kg}^{-1}$ and $I_{w}$ is the inhalation rate in $\mathrm{m}^{3} \mathrm{~h}^{-1}$. 
TABLE II

Activity concentrations $\left(\mathrm{Bq} \mathrm{kg}^{-1}\right)$ of soil samples from undisturbed land, pits, heaps and minerals. Concentrations en activité $\left(\mathrm{Bq} \mathrm{kg}^{-1}\right)$ des échantillons de sol provenant de terre, de puits, de terrils et de minerais.

\begin{tabular}{llllll}
\hline Sample & & Number & ${ }^{40} \mathrm{~K}$ & ${ }^{238} \mathrm{U}$ & ${ }^{232} \mathrm{Th}$ \\
\hline Soil & & & & \\
undisturbed land & 10 & mean $\pm \mathrm{SD}$ & $194.3 \pm 25.2$ & $14.5 \pm 5.1$ & $13.3 \pm 5.9$ \\
& & $\begin{array}{l}\text { range } \\
\text { heaps }\end{array}$ & $154.2-231.9$ & $5.2-21.0$ & $<4.8-16.9$ \\
& & mean \pm SD & $278.1 \pm 5.4$ & $21.1 \pm 2.0$ & $15.3 \pm 7.5$ \\
pits & 15 & mean \pm SD & $314.2 \pm 5.7$ & $27.7 \pm 2.6$ & $7.2-51.1$ \\
& & range & $240.8-399.1$ & $7.8-66.8$ & $11.5 \pm 5.7$ \\
Minerals & & & & & $<4.8-16.5$ \\
beryl & 1 & & $1985 \pm 16$ & $4.8 \pm 0.9$ & $11.8 \pm 5.8$ \\
feldspar & 3 & mean \pm SD & $115.1 \pm 27.9$ & $5.0 \pm 1.3$ & $6.3 \pm 5.0$ \\
quartz & 2 & mean \pm SD & $1421 \pm 122$ & $<4.8$ & $20.1 \pm 3.5$ \\
\hline
\end{tabular}

$\mathrm{SD}=$ Standard Deviation; $<$ indicates below the detection limit (BDL).

Internal dose due to inadvertent ingestion of radionuclide $E_{\text {ing }}$ can be calculated using (Mustapha et al., 2007);

$$
E_{\text {ing }}=\sum_{R} A_{R} D C_{\text {ing }, R} I_{w, \text { ing }} T
$$

where $A_{R}$ is the activity concentration of gamma-ray emitting radionuclide in soil sample $\left(\mathrm{Bq} \mathrm{kg}^{-1}\right), D C_{\text {ing, } R}$ is the internal dose coefficient for ingestion $\left(\mathrm{Sv} \mathrm{Bq}^{-1}\right)$, $I_{w, \text { ing }}$ is the ingestion rate $\left(\mathrm{g} \mathrm{h}^{-1}\right)$ and $T$ is the amount of hours per year spent by the workers in the field.

\section{Result and discussion}

The activity concentrations of ${ }^{40} \mathrm{~K},{ }^{238} \mathrm{U}$ and ${ }^{232} \mathrm{Th}$ in the soil and mineral samples are given in Table II. The activity concentrations of natural radionuclides in the soil samples from undisturbed land varied from 164.2-231.9, 5.2-21.0 and $<4.8-16.9 \mathrm{~Bq} \mathrm{~kg}^{-1}$ for ${ }^{40} \mathrm{~K},{ }^{238} \mathrm{U}$ and ${ }^{232} \mathrm{Th}$, respectively. The activity concentrations of ${ }^{40} \mathrm{~K},{ }^{238} \mathrm{U}$ and ${ }^{232} \mathrm{Th}$ in the soil from the heaps varied between 206.7-377.6, 4.5-29.3 and 7.2-51.1 $\mathrm{Bq} \mathrm{kg}^{-1}$ while those from the pits varied between 240.8-399.1, 7.8-66.8 and <4.8-16.5 $\mathrm{Bq} \mathrm{kg}^{-1}$. The mean activity concentrations of ${ }^{40} \mathrm{~K},{ }^{238} \mathrm{U}$ and ${ }^{232} \mathrm{Th}$ in the mineral samples were $115.1 \pm 27.9$, $5.0 \pm 1.3$ and $6.3 \pm 5.0 \mathrm{~Bq} \mathrm{~kg}^{-1}$, respectively for feldspar and $1421 \pm 122,<4.8$ and 
TABLE III

Calculated effective dose for miners according to exposure scenario.

Dose efficace calculée pour les mineurs selon les scénarios d'exposition.

\begin{tabular}{lccccc}
\hline Operation & \multicolumn{4}{c}{ Effective Dose $\left(\mu \mathrm{Sv} \mathrm{y}{ }^{-1}\right)$} \\
& $E_{\text {ext }}$ & $E_{\text {inh }}$ & $E_{\text {ing }}\left(10^{-5}\right)$ & $E_{\text {sub }}\left(10^{-4}\right)$ & $E_{\text {total }}$ \\
\hline digging & 81.5 & 8.4 & 2.9 & 1.3 & 89.9 \\
handling in the pits & 81.5 & 8.4 & 2.9 & 1.3 & 89.9 \\
handling on the heaps & 55.0 & 8.6 & 3.2 & - & 63.6 \\
\hline
\end{tabular}

$20.1 \pm 3.5 \mathrm{~Bq} \mathrm{~kg}^{-1}$, respectively for quartz. The activity concentrations in the beryl were $1985 \pm 16,4.8 \pm 0.9$ and $11.8 \pm 5.8 \mathrm{~Bq} \mathrm{~kg}^{-1}$, respectively for ${ }^{40} \mathrm{~K},{ }^{238} \mathrm{U}$ and ${ }^{232} \mathrm{Th}$.

In all the samples analyzed, the activity concentration of ${ }^{40} \mathrm{~K}$ was highest compared to the other radionuclides. The average activity concentration of the radionuclides in the soil samples increase in the order ${ }^{40} \mathrm{~K}>{ }^{238} \mathrm{U}>{ }^{232} \mathrm{Th}$, independent of location, that is, whether pit or heap or undisturbed land. The activity concentration of ${ }^{232} \mathrm{Th}$ in soil samples from the heap is greater than its activity concentration in soil samples from pit and undisturbed land. This is in accordance with the fact that ${ }^{232}$ Th has greater tendency of accumulation than ${ }^{40} \mathrm{~K}$ and ${ }^{238} \mathrm{U}$ because thorium is known as one of the least soluble elements whereas uranium and potassium compounds are soluble therefore; they can be partially leached from the heap (Sam and Awad Al-Geed, 2000). For the minerals, the activity concentration of ${ }^{40} \mathrm{~K}$ in beryl and quartz was very high compared to that of feldspar.

The activity concentration level of radionuclides in soil samples from undisturbed land were lower compared to the soil samples from heaps and pits with the exception of ${ }^{232} \mathrm{Th}$ which is higher than that from the pit. This shows that the mining activity has actually enhanced the activity concentration level of the naturally occurring radionuclide at the site. However the activity concentrations of the natural radionuclides in all the soil samples were below the world average for soil $\left({ }^{40} \mathrm{~K}: 420,{ }^{238} \mathrm{U}: 33\right.$ and $\left.{ }^{232} \mathrm{Th}: 45 \mathrm{~Bq} \mathrm{~kg}^{-1}\right)$ (UNSCEAR, 2000).

The effective dose to miners calculated according to exposure scenario described in this work is given in Table III. It is apparent that miners in the pit are equally exposed to the same dose irrespective of their work in the pit that is, whether digging or handling while miners that work at the heap are less exposed. When compared with the result obtained for tin tailings at mining area in Jos, Nigeria $\left(9.4 \mu \mathrm{Sv} \mathrm{h}{ }^{-1}\right)$ (Ademola, 2008), the results obtained in this work are very low. Though some of the doses are high, all of the effective doses calculated in this 
work are below the annual global effective dose of $2.7 \mathrm{mSv}$ due to natural source for miner (UNSCEAR, 2000), however the UNSCEAR annual global effective dose also considered exposure to radon gas.

\section{Conclusion}

It is obvious that the mining activity to some extent has enhanced the radioactivity concentration level of the mining area. Miners in the pits are more exposed than those that work at the heaps. The most significant contribution was from the external exposure though the doses are all below the reported UNSCEAR annual global effective dose which includes exposure to radon for miners (UNSCEAR, 2000). The miners at the site are not at any potential risk of high occupational exposure due to long lived radionuclides of ${ }^{238} \mathrm{U},{ }^{232} \mathrm{Th}$ and ${ }^{40} \mathrm{~K}$. However further study is necessary to assess the exposure due to the radioactive noble gas ${ }^{222} \mathrm{Rn}$ and its decay products. There is a possibility of ${ }^{232} \mathrm{Th}$ to accumulate probably giving higher radiation in the future if the mining activities continue. It is recommended that the miner should make use of nose mask to reduce the inhalation of soil particles and make it a habit to take a shower after work each day to wash off the particles that may stick to their body.

\section{REFERENCES}

Adekoya J.A. (2003) Environmental implication of mineral exploration, Nigeria Mining and Geosciences Society, 117-122.

Ademola J.A. (2004) Radiation dose from concrete building blocks in eight cities of Southwestern Nigeria, Ph.D. thesis, Department of Physics University of Ibadan.

Ademola J.A. (2008) Exposure to High Background Radiation Level in the Tin Mining Area of Jos Plateau, Nigeria. J. of Radiol. Prot. 28, 93-99.

Battey M.H., Pring, A. (1997) Mineralogy for students, 3rd edn. Addison and Wesley Longman Higher Education, London.

Deer W.A., Howie R.A., Zussman J. (1992) An introduction to the rock-forming minerals. Longman Scientific \& Technical, London.

Eckerman K.F., Ryman J.C. (1993) Federal Guidance Report No. 12: External exposure to radionuclides in air, water and soil (Washington, DC: US Environmental Protection Agency Office of Radiation and Indoor Air), EPA 402-R-93-081.

IAEA (1989) International Atomic Energy Agency. Measurements of radionuclides in food and the environment - A Guidebook, STI/DOC/10/295, Vienna.

IAEA (1999) International Atomic Energy Agency. Assessment of occupational exposure due to external sources of radiation, Safety Guide No. RS-G-1.3, Vienna.

IAEA (2003) International Atomic Energy Agency. Assessing radiation doses to the public from radionuclides in timber and wood product, IAEA-TECDOC-1376, Vienna.

ICRP Publication 68 (1994) Dose coefficients for intakes of radionuclides by workers, Ann. ICRP 29(1-2).

Itiola O.A. (1998) Aspect of economic geology of Olode-Falansa pegmatite deposit, Ibadan SouthWestern Nigeria, M.Sc. project, Department of Geology, University of Ibadan. 
OCCUPATIONAL EXPOSURE TO NATURAL RADIONUCLIDES

Mustapha A.O., Mbuzukongira P., Mangala M.J. (2007) Occupational radiation exposure of artisans mining columbite-tantalite in the Eastern Democratic Republic of Congo, J. Radiol. Prot. 27, 187-195.

Oatway W.B., Moobs S.F. (2003) Methodology for estimating the doses to members of the public from the future use of land previously contaminated with radioactivity, NRPB-W36 Report, Chilton, NRPB.

Pires do Rio M.A., Amaral E.C.S., Fernandes H.M., Rochedo E.R.R. (2002) Environmental radiological impact associated with non-uranium mining industries: a proposal for screening criteria, J. Environ. Radioact. 59, 1-7.

Sam A.K., Awad Al-Geed M.M. (2000) Radiological Evaluation of Gold Mining Activities in Ariab (Eastern Sudan), Radiat. Prot. Dosim. 88, 335-340.

UNSCEAR (2000) United Nations Scientific Committee on the Effect of Atomic Radiation. Sources and Effects of Ionizing Radiation. UNSCEAR publication, Vol. 1. 